\title{
A percepção discente do projeto pedagógico de um novo curso de Medicina em Minas Gerais
}

\author{
Lucas Lima Negrão, Cássia Beatriz Batista
}

\section{Resumo}

A proposta de transformação da educação médica preconiza metodologias ativas de ensinoaprendizagem com a participação do estudante na construção do conhecimento. Esse processo de mudança se sustenta nas diretrizes curriculares nacionais, bem como na concepção de saúde como fenômeno social e na consolidação de um sistema de saúde único e de qualidade. Nesse contexto, o curso de medicina da Universidade Federal de São João del-Rei/Campus Dom Bosco inicia-se em 2014 com o projeto pedagógico direcionado para a formação de um profissional generalista, humanista, crítico e reflexivo. Nesse sentido, o currículo propõe integração de conteúdos, indissociabilidade entre teoria-prática, novas metodologias de ensino, relação mais próxima entre universidade, serviços de saúde e população, experiências de avaliação integrada e de ensino modular. Diante dessa realidade, iniciamos um estudo qualitativo para investigar a percepção dos discentes do curso de medicina em relação ao projeto pedagógico em vigor. A percepção discente do curso permite não apenas conhecer a proposta pedagógica adotada, mas a vivida, incluindo assim, os estudos sobre o currículo oculto. Adotamos a análise documental como procedimento de pesquisa, mais especificamente, analisamos registros elaborados durante a visita institucional do MEC de acompanhamento da implantação do curso em 2014. As duas primeiras turmas registraram em 36 tarjetas pontos positivos e pontos negativos do curso que foram aqui analisados. $\mathrm{O}$ currículo interdisciplinar e integrado, com disciplinas práticas desde o início do curso, com turmas pequenas e professores comprometidos são os pontos positivos destacados. Na percepção dos discentes, os pontos negativos revelaram que a infraestrutura é insuficiente já que não há instalação própria ainda e há pouca preparação do corpo docente diante da nova proposta curricular. Por fim, o currículo é ao mesmo tempo elogiado, apesar de sua aplicação ainda necessitar de aprimoramentos, todavia, sua apropriação por parte de alunos e professores requer tempo e amadurecimentos coletivos.

Descritores: Educação médica; Estudantes; Currículo 